\title{
FILTERABLE SERUM CALCIUM IN LATE PREGNANT AND PARTURIENT WOMEN, AND IN THE NEWBORN
}

\author{
BY MARIE ANDERSCH AND FRED W. OBERST \\ (From the Department of Internal Medicine and the Department of Obstetrics and Gynecology, \\ State University of Iowa, Iowa City)
}

(Received for publication September 6, 1935)

It has been shown that the proportion of diffusible serum calcium is higher in pregnant than in nonpregnant women $(1,2)$, even though the total calcium is decreased during gestation (3, $4,5)$. At birth the proportion of diffusible calcium in cord blood is lower than in the maternal blood $(2,6,7)$, although the total calcium is 1 to $3 \mathrm{mgm}$. higher in the newborn $(8,9,10)$. It is still questionable whether these reported changes in the proportions of diffusible calcium in the blood during pregnancy and at birth are due to absolute changes in this fraction or are the result of changes in the total calcium.

McLean and Hastings (11) have indicated that the different values for diffusible calcium and for ionic calcium, as determined by the frog heart method, may be reconciled when account is taken of the observation that body fluids contain small amounts (maximum, $0.15 \mathrm{mM}$. per kilogram of water) of a non-ionic but diffusible form of calcium. For practical purposes, it may be assumed that the diffusible calcium consists almost entirely of ionized calcium, and represents the filterable calcium obtained by ultrafiltration. McLean and Hastings have proposed a method for determining the ionic calcium indirectly by calculations based upon the observed serum protein and total calcium, since it is their contention that " the ionization of calcium is determined primarily by an equilibrium between calcium and protein."

In this study ionic calcium values calculated by such a method will be compared with the determined filterable calcium.

\section{METHODS AND MATERIALS}

Blood was obtained from the arm veins of eight healthy nonpregnant women, from eighteen normal women in the last month of pregnancy, from twenty-five normal parturients at the time of de- livery and from the cords of their babies immediately after birth. Stasis was avoided.

After clotting had occurred, the blood was centrifuged and the serum decanted. Filterable calcium was determined by the Gregory and Andersch (12), modification of the Greenberg and Gunther (13) method and total calcium by the ClarkCollip (14) modification of the Kramer-Tisdall (15) procedure. The total nitrogen was determined by the micro-Kjeldahl method (16) and the determined nonprotein nitrogen subtracted to give the protein nitrogen which was multiplied by the factor 6.25 to obtain the total protein. In the nonpregnant group, the total serum protein was not determined but was assumed from values previously reported by one of us (4).

\section{RESULTS AND DISCUSSION}

The averages and ranges, with median values, are tabulated in Table I. In nonpregnant women the average total calcium is $10.5 \mathrm{mgm}$. per cent while in the late pregnant this value is reduced to $9.8 \mathrm{mgm}$. per cent, while in both groups the average filterable calcium is $5.2 \mathrm{mgm}$. per cent. It is evident that the increase in the percentage of filterable calcium during late pregnancy is due to a fall in the total calcium rather than to an absolute increase in the filterable portion.

The average total serum calcium from cord blood is $11.8 \mathrm{mgm}$. per cent although the maternal blood at the time of delivery contains only 10.4 mgm. per cent. The values for filterable calcium in maternal and cord blood, 5.5 and $5.3 \mathrm{mgm}$. per cent, respectively, are practically the same as the corresponding values in the nonpregnant and pregnant groups. The average percentage of filterable calcium is lower in cord blood, confirming the observations of Nicholas, Johnson, and Johnston (2), but this proportional decrease is due to the increase in the total calcium. The slightly increased value for filterable calcium (5.5 
TABLE I

Averages and ranges with median values for serum protein, total calcium, filterable calcium, and calculated ionic calcium in nonpregnant, pregnant, and parturient women and in newborn children (cord blood)

\begin{tabular}{|c|c|c|c|c|c|c|c|c|c|}
\hline \multirow{2}{*}{ Material } & \multirow{2}{*}{$\begin{array}{l}\text { Num- } \\
\text { ber of } \\
\text { cases }\end{array}$} & \multicolumn{2}{|c|}{ Serum protein } & \multicolumn{2}{|c|}{ Total calcium } & \multicolumn{2}{|c|}{$\begin{array}{l}\text { Observed filterable } \\
\text { calcium }\end{array}$} & \multicolumn{2}{|c|}{ Calculated ionic calcium } \\
\hline & & $\begin{array}{c}\text { Average } \\
\text { and range }\end{array}$ & Median & $\begin{array}{c}\text { Average } \\
\text { and range }\end{array}$ & Median & $\begin{array}{c}\text { Average } \\
\text { and range }\end{array}$ & Median & $\begin{array}{l}\text { Average } \\
\text { and range }\end{array}$ & Median \\
\hline Nonpregnant women.... & 8 & $\begin{array}{c}\text { grams per cent } \\
7.22^{*}\end{array}$ & $\begin{array}{l}\text { grams } \\
\text { per cent }\end{array}$ & $\begin{array}{c}\text { mgm. per cent } \\
10.5\end{array}$ & $\begin{array}{c}\underset{\text { per cent }}{m g m .} \\
10.4\end{array}$ & $\begin{array}{c}\underset{\operatorname{mgm} . \text { per } 100}{\text { cc. filluate }} \\
5.2\end{array}$ & $\begin{array}{c}\text { mgm. per } \\
\text { 100 cc. } \\
\text { flltrate } \\
5.3\end{array}$ & $\begin{array}{c}\text { mgm. per } 100 \\
\text { grams water } \\
5.0\end{array}$ & $\begin{array}{l}\text { mgm. per } \\
100 \text { grams } \\
\text { watert }\end{array}$ \\
\hline $\begin{array}{c}\text { Normal late pregnant } \\
\text { women ........... }\end{array}$ & 18 & $\begin{array}{c}6.08 \\
(7.13-5.00)\end{array}$ & 6.20 & $\begin{array}{c}9.8 \\
(11.2-8.2)\end{array}$ & 9.7 & $\begin{array}{c}5.2 \\
(6.6-3.2)\end{array}$ & 5.3 & $\begin{array}{c}5.0 \\
(6.2-3.6)\end{array}$ & 5.0 \\
\hline Parturient women.... & 25 & $\begin{array}{c}6.44 \\
(7.29-5.09)\end{array}$ & 6.46 & $\begin{array}{c}10.4 \\
(11.7-8.8)\end{array}$ & 10.3 & $\begin{array}{c}5.5 \\
(7.3-4.4)\end{array}$ & 5.4 & $\begin{array}{c}5.1 \\
(6.0-4.3)\end{array}$ & 5.2 \\
\hline $\begin{array}{l}\text { Newborn children (cord } \\
\text { blood) } \ldots \ldots \ldots \ldots \ldots \ldots\end{array}$ & 25 & $\begin{array}{c}5.52 \\
(6.29-4.75)\end{array}$ & 5.43 & $\begin{array}{c}11.8 \\
(12.6-10.9)\end{array}$ & 11.7 & $\begin{array}{c}5.3 \\
(6.9-3.2)\end{array}$ & 5.3 & $\begin{array}{c}6.4 \\
(7.7-5.3)\end{array}$ & 6.2 \\
\hline
\end{tabular}

* This value was not determined simultaneously with total and filterable calcium.

† The units "mgm. per $100 \mathrm{cc}$. filtrate" and "mgm. per 100 grams water" represent approximately the same terms, since the filtrate is protein free.

mgm. per cent) in parturient women may be explained on the basis of the increased concentration of serum during labor observed by Oberst and Plass (17).

In general it appears that the average values for filterable calcium are quite uniform in nonpregnant, pregnant, and parturient women, and in the newborn (cord blood). The percentage variations noted by earlier investigators are due to the variations in total calcium.

Ionic serum calcium values calculated by the method of McLean and Hastings (11) for the most part agree reasonably well with the determined values for filterable calcium in nonpregnant, pregnant, and parturient women; but in the newborn (cord blood) the average ionic calcium value ( $6.4 \mathrm{mgm}$. per cent) does not compare well with the average filterable calcium value of 5.3 mgm. per cent. This considerable variation cannot be interpreted from the present data. Apparently, there are other factors which must be considered in using the calculations proposed by McLean and Hastings, or there is some characteristic of fetal blood which disturbs the equation they have developed.

\section{SUM MARY}

1. Average values for filterable serum calcium are constant in nonpregnant, late pregnant, and parturient women and in the newborn. Reported percentage variations are due primarily to changes in the total calcium.

2. Average values for ionic serum calcium calculated from serum protein and total calcium by the method of McLean and Hastings agree reasonably with the determined filterable calcium in nonpregnant, late pregnant, and parturient women but not in newborn (cord blood), where the calculated ionic calcium is 20 per cent higher than the determined filterable calcium.

\section{BIBLIOGRAPHY}

1. Watchorn, E., and McCance, R. A., Inorganic constituents of cerebrospinal fluid. II. The ultrafiltration of calcium and magnesium from human sera. Biochem. J., 1932, 26, 54.

2. Nicholas, H. O., Johnson, H. W., and Johnston, R. A., Diffusible serum calcium in pregnancy. Am. J. Obst. and Gynec., 1934, 27, 504.

3. Cantarow, A., Montgomery, T. L., and Bolton, W. W., The calcium partition in pregnancy, parturition, and the toxemias. Surg., Gynec., and Obst., 1930, 51, 469.

4. Oberst, F. W., and Plass, E. D., The variations in serum calcium, protein, and inorganic phosphorus in early and late pregnancy, during parturition and the puerperium, and in non-pregnant women. J. Clin. Invest., 1932, 11, 123. 
5. Widdows, S. T., Calcium content of the blood during pregnancy. Biochem. J., 1923, 17, 34.

6. Aburel, E., and Ornstein-Cernantianu, E., Le calcium ultra-filtrable en obstétrique. Compt. rend. Soc. de Biol., 1930, 105, 286.

7. Timpe, O., and Hellmuth, K., Vergleichende Untersuchungen über den Kalkspiegel und die Zustandsform des Calciums bie Mutter und Kind. Arch. $f$. Gynäk., 1931, 145, 411.

8. Mull, J. W., and Bill, A. H., Calcium and inorganic phosphorus content of prenatal and postpartum serum. Am. J. Obst. and Gynecc., 1932, 23, 807.

9. Hess, A. F., and Matzner, M. J., Rickets in relation to the inorganic phosphate and calcium in maternal and fetal blood. Am. J. Dis. Child., 1923, 26, 285.

10. Plass, E. D., and Bogert, L. J., The calcium and magnesium content of the blood serum during pregnancy, labor and the puerperium. Am. J. Obst. and Gynec., 1923, 6, 427.

11. McLean, F. C., and Hastings, A. B., The state of calcium in the fluids of the body. I. The conditions affecting the ionization of calcium. J. Biol. Chem., 1935, 108, 285.
12. Gregory, R., and Andersch, M., The filterable calcium of blood serum. I. The comparison of filterable calcium of serum and total calcium of cerebrospinal fluid in normal, hyperparathyroid, and hypoparathyroid states. Am. J. M. Sc. (In press).

13. Greenberg, D. M., and Gunther, L., On the determination of diffusible and non-diffusible serum calcium. J. Biol. Chem., 1929-1930, 85, 491.

14. Clark, E. P., and Collip, J. B., A study of the Tisdall method for the determination of blood serum calcium, with a suggested modification. J. Biol. Chem., 1925, 63, 461.

15. Kramer, B., and Tisdall, F. F., A simple technique for the determination of calcium and magnesium in small amounts of serum. J. Biol. Chem., 1921, 47, 475.

16. Hawk, P. B., and Bergheim, O., Practical Physiological Chemistry. P. Blakiston's Son and Co., Philadelphia, 1931, 10th ed., p. 449.

17. Oberst, F. W., and Plass, E. D., Water concentration of the blood during pregnancy, labor and the puerperium. Am. J. Obst. and Gynec. (In press). 